\title{
Partial reversion of transformed phenotype of B104 cancer cells by antisense nucleic acids
}

\author{
Yueh-Tsern Shaw ${ }^{a}$, Shu-Huey Chang ${ }^{a}$, Shean-Tai Chiou ${ }^{b}$, Wen-Chang Chang ${ }^{\text {b,c }}$ and \\ Ming-Derg Lai ${ }^{\mathrm{d}}$
}

${ }^{a}$ Union Biotechnology Inc. P.O. Box 26-722, Taipei, ${ }^{b}$ Institute of Biochemical Sciences, College of Science, National Taiwan University, Taipei, 'Institute of Biological Chemistry, Academia Sinica, P.O. Box 23-106, Taipei, and d Depariment of Biochemistry, College of Medicine, National Cheng Kung University, Tainan, Taiwan (Republic of China)

(Received 17 September 1992)

(Revision received 7 December 1992)

(Accepted 8 December 1992)

\section{Summary}

We used antisense RNA to inhibit the expression of oncogene neu and investigated the effects of diminished neu expression on the phenotypes of B104 cells containing activated oncogene neu. Antisense MT-neu and pSV-neo plasmids were cotransfected into neuroblastoma B104 cells. Southern analysis showed the integration of antineu DNA into B104 cells. The expression of neu was inhibited up to $90 \%$ as quantitated by immunoprecipitation. The growth rate and the potential to differentiate in these transfectants were not affected as compared to the parental cell lines. The ability to grow in soft agar was inhibited more than $90 \%$ in these transfectants. Our results indicated that antisense-RNA against a specific oncogene can decrease the tumorigenicity of tumor cells but may not be able to revert it to normal cells completely.

Keywords: neu; antisense; oncogene; neuroblastoma

Correspondence to: Ming-Derg Lai, Department of Biochemistry, College of Medicine, National Cheng Kung University, Tainan, Taiwan, Republic of China.

\section{Introduction}

One effective way to modify or turn off the activity of a particular gene selectively is to create antisense molecules that bind specifically to the target gene RNA messages, thereby interrupting the translation of that gene [1-3]. Such an approach has been used to generate artificial mutants in studying the functions of oncogenes and other genes in vitro and in vivo. Antisense RNA or DNA techniques also hold promise as therapeutics in treating diseases or cancer by inhibiting the production of a specific virus-encoded protein or the expression of cancer-associated genes [4-11]. Cancer cells containing oncogenes activated by point mutation, such as ras or neu, would be the preferred choices to perform the antisense experiments, because the expression of proto-oncogene will be unaffected when selective oligonucleotides against the mutated sequences are employed [8]. However, no experimental evidences has been presented so far that anti-neu nucleic acid can revert the transformed phenotypes of cancer cells.

The activated oncogene neu is carried in the rat neuroblastoma B104 cells, which were derived from neoplasms that were induced transplacentally with nitrosourea during the 15th day of gestation [12]. The neu oncogene was detected by transfection of mouse NIH3T3 cells with genomic 
DNA from B104 cells, and isolated from foci of transformed cells [13] The oncogene neu encodes a tumor-associated antigen p185 bearing similarities to the EGP receptor [14]. The activation of neu results from a change of valine to glutamic acid in the transmembrane domain of the p185 [15]. The human neu (HER-2) has been found to be amplified in a significant proportion of human breast cancer and other carcinoma, and this amplification appears to correlate with a more malignant phenotype [16-20]. Therefore, it is important to study whether the antisense-RNA can revert the $n e u$-associated cancer cells to normal cells or cells with less transformed phenotype. In this study, we inhibited the expression of neu by introducing the anti-neu plasmid into B 104 cells. The transfectants grow normally but with little ability to grow in soft agar. The results suggest that anti-neu message can partially revert the transformed phenotype to normal cells.

\section{Materials and Methods}

\section{Cell culture}

B104 cells and the antisense transfectants were cultured in Dulbecco's modified Eagle's medium with $10 \%$ calf serum (Boehringer Mannheim), penicillin $(100 \mathrm{U} / \mathrm{ml})$, and streptomycin $\left(10^{-4} \mathrm{~g} / \mathrm{ml}\right)$. Selection for the expression of the neu gene [21] was carried out in medium containing $4 \times 10^{-4}$ $\mathrm{g} / \mathrm{ml} \mathrm{G} 418$. Induction of the metallothionein (MT) promoter was performed in medium containing 5 $\times 10^{-5} \mathrm{M} \mathrm{ZnCl}_{2}$. The MT promoter was a kind gift from Dr. Kazuo Maruyama.

\section{Transfection and selection of transfectants}

The antisense MT-neu plasmids and pSV-neo plasmid were cotransfected into half-confluent B104 cells at the ratio of 10:1 by the calcium phosphate method [22]. Cells were subcultured and subjected to selection in medium containing G418. G418 resistant colonies were isolated 2 weeks later using cloning cylinders.

\section{DNA isolation and Southern blotting}

Genomic DNA was isolated by standard method [23]. Ten micrograms of DNA was digested with EcoR I and separated in $0.8 \%$ agarose gel.
Blotting of DNA to nitrocellulose was done as described by Southern [24]. Probes with high specific activity was prepared by random-primed DNA labeling kit (Boehringer Mannheim). The probe for hybridization is $0.7 \mathrm{~kb}$ Pst I-Sma I fragment of neu cDNA [14].

\section{Immunoprecipitation}

Cells were grown to $80 \%$ confluent in $10-\mathrm{cm}$ dishes in DMEM 10\% calf serum, and $5 \times 10^{-5}$ $\mathrm{M} \mathrm{ZnCl}$. Cells were then starved in methioninefree medium for $1 \mathrm{~h}$, and labeled with $\left[{ }^{35} \mathrm{~S}\right]$ methionine for $6 \mathrm{~h}$. Cells were lysed in lysis buffer containing $50 \mathrm{mM}$ Tris, $1 \% \mathrm{NP}-40,0.1 \%$ sodium deoxycholate, $0.15 \mathrm{M} \mathrm{NaCl}, 1 \mathrm{~m}$ MPMSF, $4 \mathrm{mM}$ EDTA, $2 \mathrm{mM}$ vandate, and $10 \mathrm{mM}$ sodium fluoride. Lysates were centrifuged at $30000 \times g$ for $30 \mathrm{~min}$. The anti-neu antibody (Ab3 from Oncogene Science) was added to the supernatant for incubation of $2 \mathrm{~h}$. The immunocomplexes were collected using protein A-sepharose, and resuspended in electrophoresis sample buffer for separation on $7 \%$ polyacrylamide gel.

\section{Soft agar assay}

The assay was performed as described by Rizzino [25]. The base layer is $0.6 \%$ agar (agar noble from Difco) in culture medium containing $10 \%$ calf serum. Cells were trypsinized and plated $2 \times$ $10^{3}$ cells $/ 10-\mathrm{cm}$ dish in $5 \mathrm{ml}$ culture medium containing $10 \%$ calf serum and $0.3 \%$ agar on the top of solidified base layer. Both layers contain $5 \times$ $10^{-5} \mathrm{M} \mathrm{ZnCl}_{2}$. Once the top layer has been added and solidified, the dishes are incubated at $37^{\circ} \mathrm{C}$ in a $5 \% \mathrm{CO}_{2}$ atmosphere.

\section{Results and Discussion}

The full length neu $4.7 \mathrm{~kb}$ cDNA was inserted in the opposite orientation, under the control of metallothionein promoter as shown in Fig. 1 [26]. Downstream of neu gene are the simian virus 40 small $\mathrm{t}$ antigen splice and polyadenylation sites. The backbone of this vector is derived from pUC18. The anti-neu plasmid generates a 9-kb linear fragment when digested with $E c o$ R I.

Thirteen G418-resistant colonies were isolated when B104 cells were transfected with both 


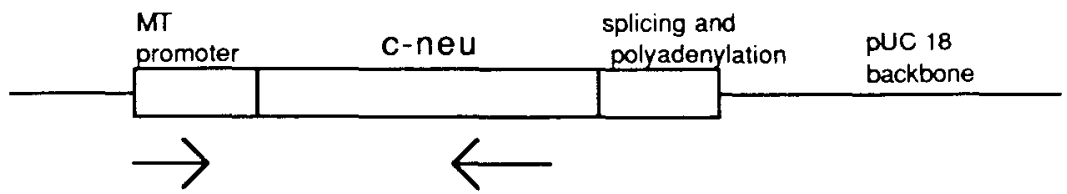

Fig. 1. The map of anti-neu plasmid DNA. The arrows indicates that the neu cDNA is in the opposite orientation relative to the promoter.

anti-neu and pSV-neo plasmids, and the presence of integrated anti-neu DNA in the transfectants was demonstrated by Southern blot analysis. Seven of the 13 clones, C-1, C-2, C-4, C-8, C-10, $\mathrm{C}-12$ and $\mathrm{C}-13$, contained anti-neu plasmid DNA. A representative Southern blotting is shown in Fig. 2. The presence of strong $9 \mathrm{~kb}$ band in lane 2 and 3 indicates the integration of multiple copies of anti-neu plasmid in the genomic DNA of C-1 and $\mathrm{C}-10$ transfectants. The $9 \mathrm{~kb}$ band was not observed in the parental B104 cells (lane 1, Fig. 2).
The amount of neu-encoded protein p185 was determined in the transfectants and B104 cells by immunoprecipitation with monoclonal antibody against p185. As shown in Fig. 3, the level of p185 in C-1, C-10, and C-12 transfectants were markedly reduced comparing with that of B104 cells. This result indicates that the expression of oncogene neu was inhibited more than $90 \%$ in these transfectants.

Tumorigenicity of the transfectants was determined in vitro by soft agar assay. The ability of

\subsection{Kb-}
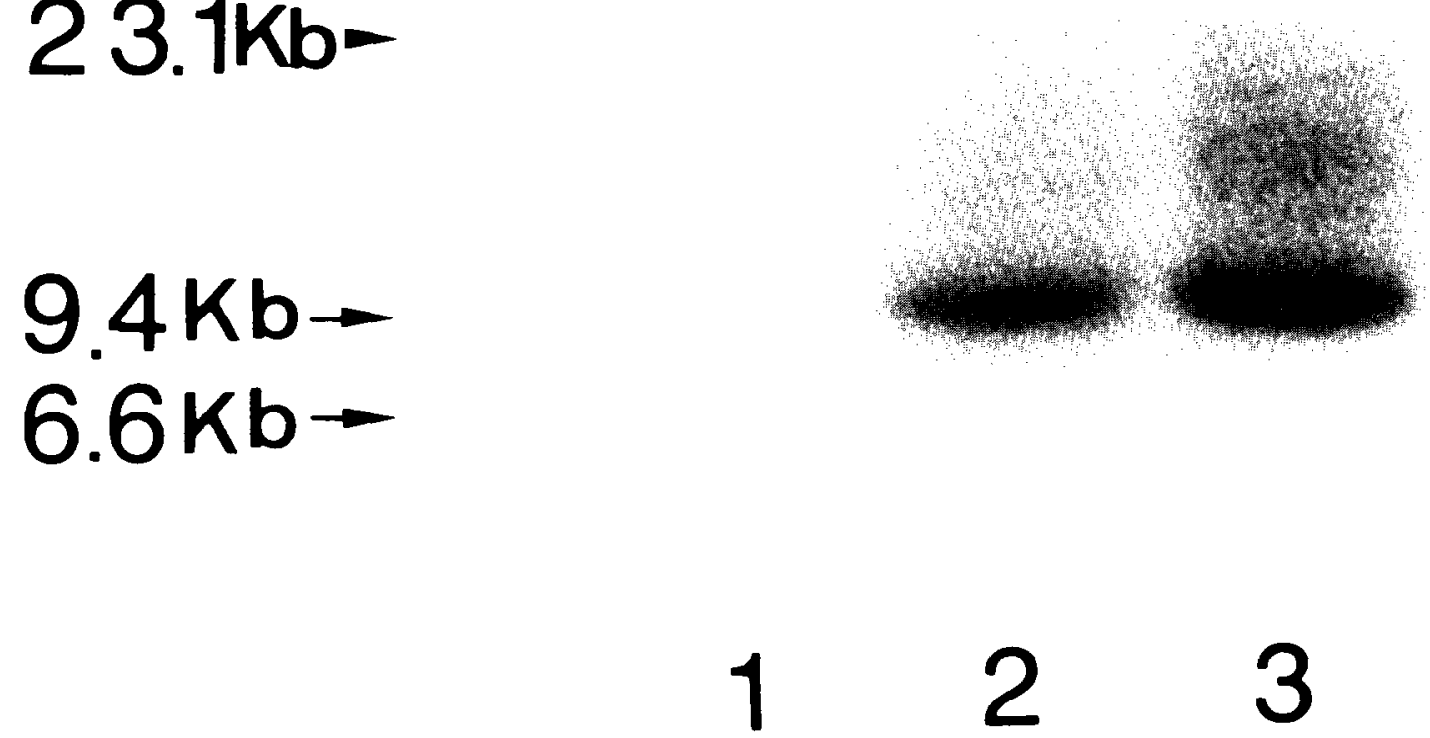

Fig. 2. Southern analysis of the anti-neu DNA. EcoR I digested genomic DNA from B104, C-1 and C-10 cells were probed with PstI-Sma I fragment of neu cDNA. Lane 1, B104 cells; lane 2, C-1 transfectants; lane 3, C-10 transfectant. Lambda phage Hind IIgenerated fragments were used as molecular weight markers in kilobases. 


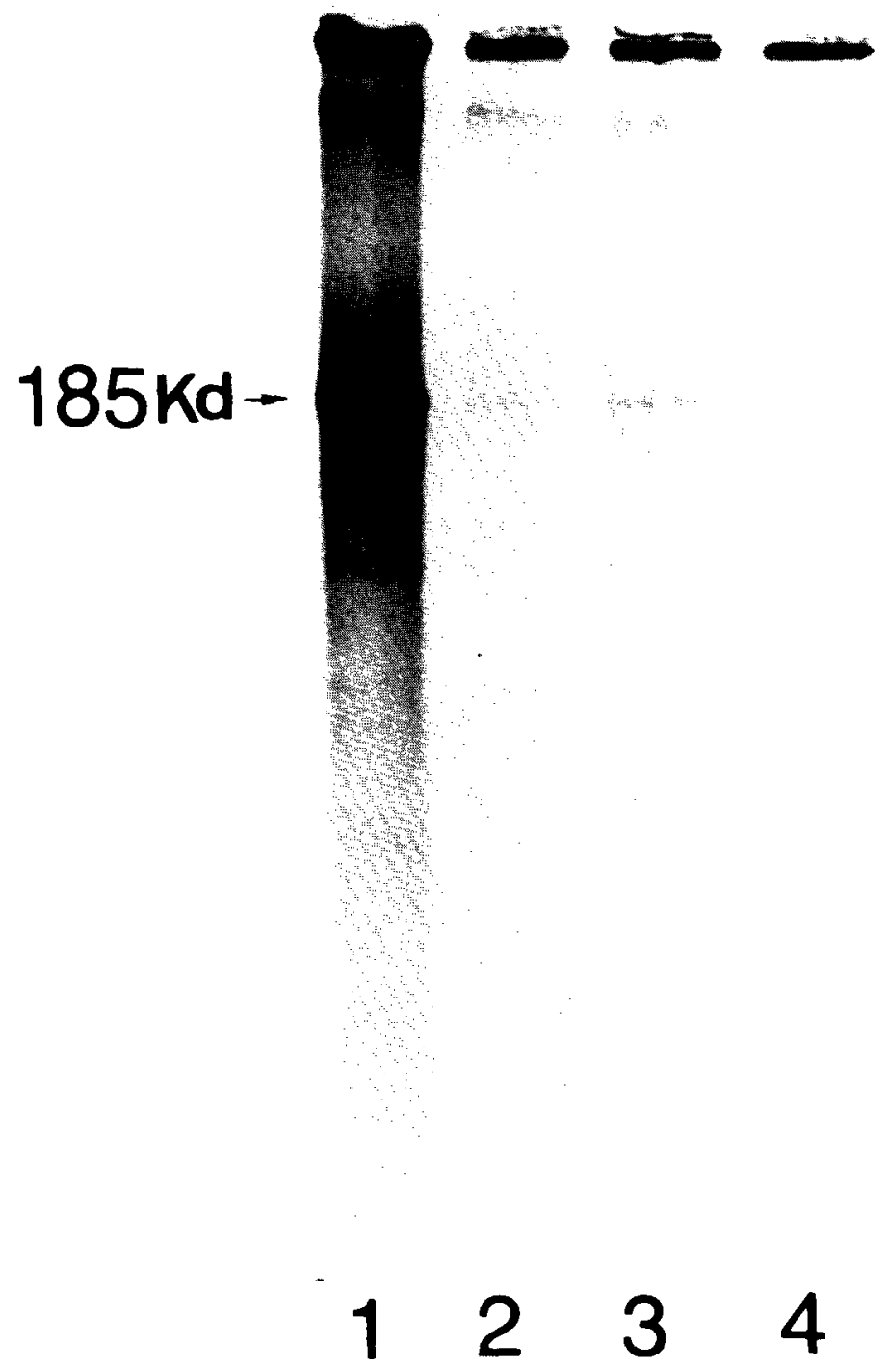

Fig. 3. SDS-PAGE analysis of anti-neu immunoprecipitates from metabolically labeled cells. $\left[{ }^{35}\right.$ S]methionine-labelled cells of B104 and three transfectants were immunoprecipitated with monoclonal anti-neu anibodies as shown. Lane 1, B104 cells; lane 2, C-1 transfectant; lane 3, C-10 transfectant; and lane 4, C-12 transfectant. The precipitation of the 185-kDa polypeptide was indicated by the arrow.

cells to grow in soft agar correlates well with the ability to form tumor in vivo [27]. B104 cells gave rise to many colonies after being seeded in $0.3 \%$ soft agar for 2 weeks, while normal NIH3T3 cells did not form any colony. The anti-neu transfectants lost most of the ability to grow in soft agar, and formed few or no colonies (Table I). The growth rates of B104 cell line and other transfectants in $10 \%$ calf serum are almost identical (Fig. 4); therefore, decreased colony formation observed here is unlikely to be due to different growth rates. The control transfectants L1 and L2, which only 
Table I. Soft agar assay of B104 cells and transfectants.

\begin{tabular}{lc}
\hline Cell Lines & No. of colonies $^{\mathrm{a}}$ \\
\hline B104 & 39 \\
NIH3T3 & 0 \\
L-1 & 41 \\
L-2 & 35 \\
C-1 & 1 \\
C-2 & 8 \\
C-4 & 3 \\
C-8 & 2 \\
C-10 & 0 \\
C-12 & 2 \\
C-13 & 4
\end{tabular}

${ }^{a}$ The average number of three independent experiments.

pSV-neo integrated, grow in soft agar as well as parental B104 cells. This suggests that loss of growth in soft agar was not due to transfection or selection process. The soft agar results indicated that the anti-neu transfectants has lost one important property of tumor cells, anchorageindependent growth. The inhibition of growth in

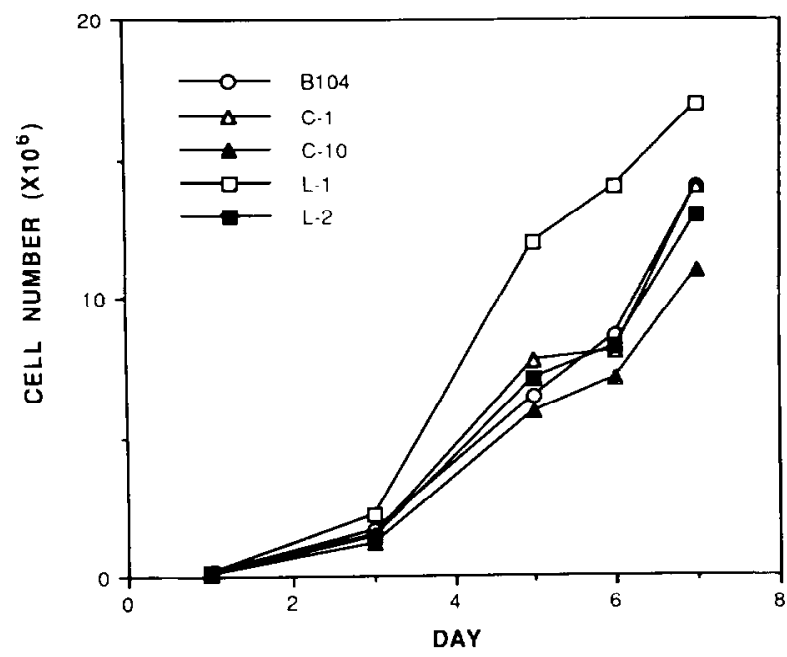

Fig. 4. Growth rates of $\mathrm{Bl04}$ cells and the transfectants. $1 \times 10^{5}$ cells of B104 cells (circles), C- 1 (open triangles), C-10 (closed triangles), L-1 (open squares) and L-2 (closed squares) transfectants were innoculated on the $9-\mathrm{cm}$ plastic dishes. The dishes were cultured in the $10 \%$ calf serum with $5 \times 10^{-5} \mathrm{M}$ $\mathrm{ZnCl}_{2}$ and on the indicated days cell numbers were determined in duplate cultures. The average cell number are shown soft agar was observed in almost all transfectants containing anti-neu, which rules out the possibility that the reversion is due to inactivation of cellular gene by random integration of plasmid DNA.

However, the anti-neu transfectants seems to retain a little ability to grow in soft agar as shown in Table I. Therefore, the antisense technique may be an effective way to repress the transformed phenotype of cancer cells but cannot completely revert the cancer cells to normal cells, at least in the B 104 cells we examined here.

The proto-oncogenes have been shown to be involved in cellular differentiation in several cell lines, for example, anti-myc message has been shown to accelerate differentiation in Friend murine erythroleukemia cells [28]. Therefore, the transfectants were further assayed for the ability to differentiate. Neutrite extension was observed in the transfectants in the presence of $1 \mathrm{mM}$ dibutyryl cAMP or serum starvation (data not shown). The inhibition of neu expression was not able to affect normal differentiation of B104 cells as judging from morphological observation. However, it cannot be excluded that very low amounts of p185 are sufficient for differentiation of B104 cells.

Our current studies have demonstrated that anti-neu message can partially though not completely revert the cancer cells to normal cells. Cancer cells from primary tumor are known to contain multiple mutations and many activated oncogenes [29]. Our present study suggests that antisense nucleic acids against one of the activated oncogenes are able to suppress the transformed phenotype remarkably.

\section{Acknowledgements}

This work is supported by grant (NSC-78-0412B-002-163) from National Science Council in Taiwan, Republic of China. I am grateful to Dr. Robert A. Weinberg for providing the B104 cells, and to Dr. Mien-Chie Hung for the gift of neu cDNA.

\section{References}

1 Izant J.G. and Weintraub H. (1984) Inhibition of thymidine kinase gene expression by anti-sense RNA: a molecular approach to genetic analysis. Cell, 36, 1007-1015. 
2 Weintraub, H.M. (1990) Antisense RNA and DNA. Sci. Am., 262, 40-46.

3 Moffat, A.S. (1991) Making sense of antisense. Science, 253, 510-511.

4 Schonthal, A., Herrlich, P., Rahmsdorf, H.J. and Ponta, H. (1988) Requirement for fos gene expression in the transcriptional activation of collagenase by other oncogenes and phorbol esters. Cell, 54, 325-334

5 Giebelhaus, D.H., Eib, D.W. and Moon, R.T. (1988) Antisense RNA inhibits expression of membrane skeleton protein 4.1 during embryonic dovelopment of Xenopus. Cell, 54, 601-615.

6 Rodermel, S.R., Abbott, M.S. and Bogorad, L. (1988) Nuclear-organelle interactions: nuclear antisense gene inhibits ribulose bisphosphosphate carboxylase enzyme levels in transformed tobacco plants. Cell, 55, 673-681.

7 Ledwith, B.J., Manam, S., Kraynak, A.R., Nichols, W.W. and Bradley, M.O. (1990) Antisense-fos RNA causes partial reversion of the transformed phenotypes induced by the c-Ha-ras oncogene Mol. Cell. Biol., 10, 1545-1555

8 Ratner, M. (1989) Can the antisense message be delivered. Biotechnology, 7, 207

9 Walder, J. (1988) Antisense DNA and RNA: Progress and Prospects. 2, 502-504.

10 Whitesell, L., Rosolen, A. and Neckers, L.M. (1991) Episome-generated $\mathrm{N}-m y c$ antisense RNA restricts the differentiation potential of primitive neuroectodermal cell lines. Mol. Cell. Biol., 11, 1360-1371.

11 Szczylik, C., Skorski, T., Nicolaides, N.C., Manzella, L., Malaguarnera, L., Venturelli, D., Gewirtz and Calabretta, B. (1991) Selective inhibition of leukemia cII proliferation by bcr-abl antisense oligodeoxynucleotides. Science, 253. $562-565$.

12 Schubert, D., Heinemann, S., Carlisle, W., Tarikas, H., Kimes, B., Patrick, J., Steinbach, J.H., Culp, W. and Brandt, B.L. (1974) Clonal cell lines from the rat central nervous system. Nature, 249, 224-227.

13 Hung, M.C., Schechter, A.L., Chevray, P.Y., Stern, D.F. and Weinberg, R. A. (1986) Molecular cloning of the neu gene: absence of gross structural alteration in oncogenic alleles. Proc. Natl. Acad. Sci., 83, 261-264.

14 Bargmann, C.I., Hung, M.C. and Weinberg, R.A. (1986) The neu oncogeneencodes an epidermal growth factor receptor-related protein. Nature, 319, 226-230.

15 Bargmann, C.I., Hung, M.C. and Weinberg, R.A. (1986) Multiple independent activations of the neu oncogene by a point mutation altering the transmembrane domain of p185. Cell, 45, 649-657.

16 Yamamoto, T., Ikawa, S., Akiyama, T., Semba, K., Nomura, N, Miyajima, N., Saito, T. and Toyoshima, K. (1986) Similarity of protein encoded by the human c-erbB-2 gene to epidermal growth facor receptor. Nature, 319 , 230-234.
17 Zhou, D., Battifora, H., Yokota, J., Yamamotto, T. and Cline, M.J. (1987) Association of multiple copies of the cerbB-2 oncogene with spread of breast cancer. Cancer Res., 47, 6123-6125.

18 Slamon, D.J., Godolphin, W., Jones, L.A., Holt, J.A., Wong, S.G., Keith, D.E., Levin, W.J. Stuart, S.G., Udove, J., Ullrich, A. and Press, M.F. (1989) Studies of the HER-2/neu proto-oncogene in human breast and ovarian cancer. Science, 244, 707-712.

19 Hung, M.C., Zhang, X., Yan, D.H., Zhang, H.Z., He, G.P., Zhang, T.Q. and Shi, D.R. (1992) Aberrant expression of the c-erbB-2/neu protooncogene in ovarian cancer. Cancer Lett., 61, 95-103.

20 Shi, D., He, G., Cao, S., Pan, W., Zhang, H.Z., Yu, D. and Hung, M.C. (1992) Overexpression of the c-erbB$2 /$ neu-encoded p185 protein in primary lung cancer. Mol. Carcinogen., 5, 213-218.

21 Southern, P.J. and Berg, P. (1982) Transformation of mammalian cells to antibiotic resistance with a bacterial gene under control of the SV40 early region promoter. $J$. Mol. Appl. Genet., 1, 327-341.

22 Parker, B.A. and Stark, G.R. (1979) Regulation of simian virus 40 transcription: sensitive analysis of the RNA species present early in infections by virus or viral DNA. J Virol., 31, 360-369.

23 Maniatis, T., Fritsch, E. and Sambrook, J. (1982) Molecular Cloning: A Laboratory Manual. Cold Spring Harbor, New York: Cold Spring Harbor Laboratory.

24 Southern, E.M. (1975) Detection of specific sequences among DNA fragments separated by gel electrophoresis. J. Mol. Biol., 98, 503-517.

25 Rizzino, A. (1987) Soft agar assays or transforming growth factors and mitogenic peptides. Methods Enzymol., 146, 341-352.

26 Stuart, G.W., Searle, P.F., Chen, H.Y., Brinster, R.L. and Palmiter, R.D. (1984) A 12-base-pair DNA motif that is repeated several times in metallothionein gene promoters confer metal regulation to a heterologous gene. Proc. Natl. Acad. Sci., 81, 7318-7322.

27 Ruddon, R.W. (1987) Cancer Biology, 2nd edn. Oxford University Press, Inc. New York

28 Prochownik, E.V., Kukowka, J. and Rodgers, C. (1988) $\mathrm{C}-m y c$ antisense transcriptsaccelerate differentiation and inhibit $\mathrm{G} 1$ progression in murine erythroleukemia cells. Mol. Cell. Biol., 8, 3683-3695.

29 Weston, A., Willey, J.C., Modali, R., Sugimura, H., McDowell, E.M., Resau, J., Light, B., Haugen, A., Mann, D.L. and Trump, B.F. and Harris, C.C. (1989) Differential DNA sequence deletions from chromosome 3,11, 13 and 17 in squamous-cell carcinoma, large-cell carcinoma and adenocarcinoma of the human lung. Proc. Natl. Acad. Sci., 86, 5099-5103. 